\title{
Day Wise Trend of the Environmental News Published Per Month: A Critical Study
}

\author{
Arup Guchhait \\ Research Scholar, University of Calcutta and Public Relation Officer, West Bengal Pollution Control \\ Board(Department of Environment, Government of West Bengal)
}

Prof. (Dr.) TapatiBasu

Professor, Department of Journalism \& Mass Communication, University of Calcutta

Tushar Kanti Ghara

Joint Director of Public Instruction, Government of West Bengal

\begin{abstract}
Media has a massive role in communicating information in various kinds. Particularly, the print media is serving society powerfully with their development in various fields including technological aspects. Within the sharp competition each media wants to hold their audience with continuous innovative items. Environment is such a contemporary subject which has a fair demand. The space is so valuable. In this study, the status of the English and the Bengali dailies in connection with environmental journalism, especially the most available 'categories' in local newspapers have been scrutinized. All the local newspapers played an influential role to upgrade society environmentally by publishing environmental news and a decreasing trend of number of news published per day towards the end of the month has been shown.
\end{abstract}

Keywords: Newspaper, Environment, News, Decreasing number

\section{INTRODUCTION}

Alexander the Great has been known as unconquered king and one of the history's most successful military chiefs. ${ }^{1} \mathrm{He}$ was a King of the Ancient Greek kingdom of Macedonia, which was an ancient kingdom on the northern periphery of Classical Greece ${ }^{2}$ and later the dominant state of Hellenistic Greece. ${ }^{3}$ Alexander spent most of his reigning period on an unmatched military operation through Asia and northeast Africa. He had shaped one of the largest kingdoms of the ancient world, extending from Greece to north-western India by the age of thirty. ${ }^{4}$

Alexander established some twenty cities that bore his name, most notably Alexandria in Egypt and Alexandria Troas in Turkey. ${ }^{5} \mathrm{He}$ strongly set up Greek colonists resulted the spreading of Greek culture in the east and introduced Hellenistic civilization, features of which were still found in the societies of the Byzantine Empire in the mid-15th century and the presence of Greek speakers in central and far eastern Anatolia until the 1920s. ${ }^{67}$ Alexander turned out to be a legendary and a classical hero in the mould of Achilles featuring prominently in the history and mythic traditions of both Greek and non-Greek cultures. He set up a standard of heroism on which other military leaders of the world are measured by the historians. Alexander's military genius is unquestionable. He upgraded the strong army inherited from his father, Philip II. He strengthened the cavalry arm, employed weapons specialists and a corps of engineers. He was invincible in both siege warfare and set battles. His movements were marked by speed. Alexander's logistical facilities, sharp intelligence, and timely communication operations were perfect and his ability to improvise was supreme. Yet he was always careful in strategy. ${ }^{8}$ Still his war tactics are taught in different military academies throughout the world. ${ }^{910}$ Alexander is also considered among the top influential people in human history, along with his teacher Aristotle. ${ }^{11}$

Alexander was born in Pella in 356 BC succeeded his father, Philip II at the age of only twenty. He was educated by the great philosopher Aristotle until the age of 16. Alexander sat his father's throne after Philip's assassination in $336 \mathrm{BC}$. He was conferred the Generalship of Greece and used this power to introduce his father's PanHellenic project to lead the Greeks in the conquest of 
Persia. ${ }^{121314}$ Alexander basically started his military campaign in 334 BC. First he occupied the Achaemenid Empire (founded by Cyrus the Great, famous for including various civilizations and becoming the largest empire of ancient history), and began a series of operation for next 10 years.

Most probably, to satisfy his adventurous hunger, Alexander invaded India in 326 BC. He wanted to reach "ends of the world and the Great Outer Sea", he attacked India. He invited so many kings to come to him and submit to his authority. Some of the Indian Kings like Omphis (known asAmbhi), the ruler of Taxila complied and some others like Aspasioi and Assakenoi sections of the Kambojas (known in Indian texts also as Ashvayanas and Ashvakayanas) refused to submit. ${ }^{15} \mathrm{He}$ faced strong battle against the Aspasioi of Kunar valleys, the Guraeans of the Guraeus valley, and the Assakenoi of the Swat and Bunervalleys. ${ }^{1617}$

King Purus was then a strong ruler of a region lying between the Hydaspes and the Acesines (Chenab), in what is now the Punjab. Alexander crossed the Indus and won an epic battle against King Porus in the Battle of the Hydaspes in $326 \mathrm{BC} .{ }^{18}$ Then Alexander wanted to win over Nanda Empire of Magadha, east of Puru's Kingdom, near the Ganges and Gangaridai Empire, further east. Both the Empires were enough strong, having huge army strength. But, he turned back at the demand of his troop. There were two reasons of this demand of his troop i.e. extreme tiredness for years of military campaigning and fear the view of facing other two large strong armies. Eventually, Alexander's army revolted at the Hyphasis River (Beas), denying to forward farther east. This river thus marks the easternmost range of Alexander's takeovers. ${ }^{19}$ Alexander died in Babylon in $323 \mathrm{BC}$.

Existence of mass media was then beyond imagination in around 350 BC. Social communication process was different. Mass communication did not have any importance. Otherwise, media could have triggered people to resist Alekxander's penetration, helped Indian to take more powerful strategy. Mass media could highlight the strength of enemies, their strategies, daily progress of foreign invaders, highlight the war report, and generate patriotism. And all these power of media might create a new direction of the Indian history.

On the other hand, the canonization programme at Vatican City on 04.09.2016, where Mother Teresa became Saint Teresa of Kolkata, was covered by the media of all parts of the world. Innumerable numbers of journalists reported the grand programme from Vatican. Spectators across the globe watched the holy programme minute by minute in electronic media. Detailed reporting was also found in print media. The strength of mass media showcased the transition of Teresa from 'Mother' to 'Saint'. Not only the Christians, not only the missionaries, whole of the world offered their homage to the Saint Teresa. This was possible only for the presence of global media.

The print media is one of the oldest traditional media. Since the inception, it is facing several challenges from time to time. Print media faced challenges mainly from the new technologies developed in different period of time. Even it is considered that the environment has been threatened by the publication of print media due to consumption of a large amount of tree for paper. A rule of thumb is that a piece of hardwood (128 cubic feet) weighing two tons will produce 1,000 to 2,000 pounds of paper. So, it is imagined that the number of trees needed for a ton of paper. ${ }^{20}$ Cracking all the challenges, print media is still dominating throughout the world.

A section of media researchers are telling that electronic media is grasping print media slowly but surely. Electronic media is faster in nature and comparatively up to date. On the other hand, print media is more accurate and precise. Electronic media is basically more interactive and has no specific deadline. ${ }^{21}$ Print media has also run always under specific deadline, so that the printed copies may be reached in different places.

The electronic media revolution has reintroduced discussion about print media's importance. In actuality, both communication forms have advantages and disadvantages. Journalists of Print media may cover issues with greater depth than the journalists of electronic media. However, electronic media's capability to break news at lightning speeds is marked as a key factor for endangering the readership of print media. ${ }^{22}$

A number of new threats have matured recent years to the print media industry. Internet is the utmost challenge to the print media now. Audience are getting all kinds of news at the cost of few clicking. Internet provides largest platform to find numerous type of current news. Now, Mobile has emerged as new tool to get all latest news using latest technology. Readers start preferring internet based media 
for reading and viewing news and other information. This trend of continuous shifting of audience from print media to internet media is increasing speedily specially in developed and developing countries. It is obvious that this trend is clearly prominent in those countries of high literacy. Beside internet, 24 hours of news in television channels and the radio are throwing challenge daily basis to the print media. It also to be mentioned that television and radio channels are mushrooming in such a speed, new newspapers are not emerging in such pace. Moreover, new generation does not have such habit or patience to read out a newspaper thoroughly. In their busy schedule, they want to enjoy media information at the time of doing something else simultaneously. This is also one of the prominent causes of increasing demand of electronic media. This should also to be mentioned that demand of electronic media is increasing along with the increasing of circulation of print media in those developed or developing countries which have a high literacy rate.

It is still uncertain whether the mass media endorse environmental apathy or action though it is clear that media play an imperative role in the social construction of environmental concern. Several studies are continuing to understand the public perception of environmental issues. Public perceptions of environmental degradation, myths, beliefs, risk, understandings, politics, and attitudes are the key areas of studies. Different techniques are adopted in various studies from which media researchers are trying to get answers of innumerable questions.

It has been stated that public perceptions of environmental concern depend largely on the mass media. ${ }^{23}$ A. Downs' 1972 article entitled "Up and down with ecology" lays out a public interest cycle that many major issues go through in modern political life. As Downs mentioned it that "American public attention rarely remains sharply focused upon any one domestic issue for very long-even if it involves a continuing problem of crucial importance to society. Instead, a systematic "issue-attention cycle" seems strongly to influence public attitudes and behaviour concerning most key domestic problems. Each of these problems suddenly leaps into prominence, remains there for a short time, and then - though still largely unresolved - gradually fades form the center of public attention." ${ }^{24}$ However, the impact of the media on building public perception depends on how the news has been interpreted by the readers. It has also been shown in some studies that mass media also promotes public opinion, political action and protest. ${ }^{2526}$ Other researchers argue that the media usually publishes indifference and pessimism rather than active citizenship. Though, there is no doubt that readers set their own agenda socially on the basis on media presentation. ${ }^{27}$

In India, the status of the print media industry is not bad and not so good also. Specifically it is almost in balanced situation. The circulation of some Indian newspapers has increase remarkably. Similarly the circulation of some Indian newspapers has decreased severely. Basically, the Press in India is very vibrant. It is changing speedily with following changes in the society. Moreover, technology pushes media world to induce contemporary changes.

Department of Communication \& Journalism, University of Pune prepared a status report which was submitted to The Press Council of India namely "Review of The Press in India(2008 to 2012). According to that report some of the following interesting facts have been observed:-

- There are 2.5 billion People have a habit of reading a newspaper in print regularly. On the other hand, the 2.2 billion people use internet, or who have the ability to go through the content on mobile telephones.

- More than 500 million people read the print and digital form of newspaper. On the other hand, only 100 million more read the digital version only.

- Worldwide newspaper circulation has been increased by 1.1 per cent in 2011 , to 512 million copies, and 4.2 per cent between 2007 and 2011.(Source: 'World Press Trends' 2012)

It is most important that the Asian newspapers contributed the most in this growing trend. They have balanced the damages in other parts of the world, mostly in North America and Western Europe. As per 'World Press Trends' (WPT) 2012 Report, a total of 17 per cent circulation of print media has been dropped during 2007 to 2011in those areas. This is a very grave situation for the newspapers. In case of year by year calculation, it is seen that almost 4.3 per cent circulation has been dropped in North America, almost 3.3 per cent in Latin America and almost 3.4 percent in Europe. On the other hand, a total of 16 per cent circulation of Asian newspapers has been grown. Almost 3.5 per cent newspaper circulation has been grown year by year in Asian region and almost 4.8 per cent in Middle East and North Africa. Mainly the print media industry has flourished in India and China. Newspaper circulation in Australasia region was remained same. 
As per 'World Press Trends' 2012 Report, it is cleared that the audience are keen to spend more and more time with television and radio. According to that report, media consumption rate has been raised remarkably during 2007 to 2011 by only a few minutes to approximately 400 minutes a day. Average time span for newspaper reading has remained moderately unchanging, but an internet usage level during this period has risen by 20 minutes. But online reading habit has increased. WAN-IFRA study says that about 40percent of global digital audience read a newspaper online or on mobile platforms. This is also a hopeful fact for the newspaper industry. ${ }^{28}$

In this regard, one comment written in WPT 2012 report should be mentioned now that is 'Newspapers are changing and must change, if they are to continue fulfilling their traditional role as watchdogs, and as the provider of credible news and information that citizens need to make informed decisions in society. Digital audiences are growing. But digital revenues are slow to follow. The problem is not one of audience, newspapers have the audience. The challenge is of finding successful business models for the digital age.'

Now, the status of Indian print media should be reviewed. The Registrar of the Newspapers for India (RNI), under Ministry of Information and Broadcasting, Government of India publishes important statistical report related to the Indian Press every year. It brings out all possible important information of Indian print media industry. RNI showed the strength and the progress of Indian newspaper industry in its 'Press in India' annual report of 2010-2011. As per RNI report, the number of daily newspaper published in India in 2010-11 was 4,396 as against 3909 in 2009-10. This is remarkably $11 \%$ growth. Even the claimed circulation of dailies in the same period has been increased by $8.23 \%$. 'Press in India', annual report 2010-2011 also focused the circulation figures of dailies for last ten year that presents an idea about the firm growth in circulation of newspapers in India. ${ }^{29}$ The table of it is given below.

Circulation of newspapers (2001 to 2010-11)

\begin{tabular}{|c|c|}
\hline YEAR & DAILIES \\
\hline 2001 & $5,78,44,236$ \\
\hline $2002-03$ & $7,29,38,646$ \\
\hline $2003-04$ & $7,35,37,182$ \\
\hline $2004-05$ & $7,86,89,266$ \\
\hline $2005-06$ & $8,88,63,048$ \\
\hline $2006-07$ & $9,88,37,248$ \\
\hline $2007-08$ & $10,57,91,199$ \\
\hline $2008-09$ & $13,58,05,315$ \\
\hline $2009-10$ & $16,23,12,686$ \\
\hline $2010-11$ & $17,56,65,243$ \\
\hline
\end{tabular}

It is clear from the above table that circulation has been steadily increased in India year by year.

Healthy circulation of a newspaper depends on so many factors among them news content is one of the major ones. Environmental news is now treated as one of the demanding contemporary contents. All the major print media now prefer environmental issues to be picked up regular basis. Some of the environmental issues are now international concern.

Now, the research question is: What is the trend of number of news published date wise per month?

\section{Conceptualization}

Environmental news published in Dailies have been classified into several "News Type". Among them only major seven (07) categories like comments, editorial, features, general news, hard news, letter, photo news have been studied here. Usually all the categories of news have their own characteristics. Only any doubt or confusion may be raised between general news and hard news. News of both the categories has different news value. News value depends on four (04) basic factors like importance, proximity, size and timeliness. ${ }^{30}$

General news is more casual in nature than hard news.

Hard news always possesses the better significance of effectiveness, timely actions and results than any general news. Though, this may be mentioned that the gap between these two categories is not so prominent. Even also, it is not easy job to differentiate both the categories every time. 
Carrying opinion of the citizens or audience is perhaps the most treasured part of the mass media in this information age. It is now very easy to get information about the actions taken by the government from different mass media. It is also easy to get and share opinions on specific issue. Audience can harmonise opinion of one's own. In most of the cases, mass media take nonpartisan stand and accept opinions based on different school of thoughts. In case of electronic media, debate on specific issue is frequently seen. Online sources like blogs, emails exclusively handled by any individual are the key components of such debates in electronic media. In print media, 'letter to the editor' is the only platform to share the readers' opinions. Sometimes print media itself feel to find opinion of readers on any issue. In that case, print media collect opinion by interviewing experts, concerned people and general mass.

Editorial is the mirror of a newspaper and it projects the viewpoint of the newspaper on a particular policy. ${ }^{31}$ Usually a group of senior journalists are involved in writing daily editorial. Some of the newspapers used to publish more than one editorial. Specialised features and other columns are also found in local print media regular basis. Feature has a great importance in all newspapers. News does not carry previous records, future consequences, and does not have documentation value etc. Feature focuses on overview details and possesses documentation value.

All photographs which were published in nine prominent dailies during January to March, 2005 have been divided into eight (08) further types like Colour(Natural), Black \& White (Natural), Colour (Symbolic), Black \& White (Symbolic), Collage (Colour), Collage (Black \& White) Sketch (Colour), Sketch (black \& White).

Published news were also categorized into three (03) i.e. local, national and international vide the content of the news in respect of place of interest.

\section{Methodology}

Nine prominent newspapers of five long years (edition of $1^{\text {st }}$ January, 2005 to $31^{\text {st }}$ December, 2010) have been monitored critically. In the category of prominent dailies, following publications published from Kolkata have been studied:-

1. The Telegraph (English)

2. The Statesman (English)

3. The Times of India (English)

4. Hindustan Times (English)

5. Anandabazar Patrika (Bengali vernacular)

6. Bartaman (Bengali vernacular)

7. Aajakal (Bengali vernacular)

8. Sambad Pratidin (Bengali vernacular)

9. Ganashakti (Bengali vernacular)

These are the most populated and widely circulated newspapers during 2005 and 2010 in Kolkata. One glimpses of average qualifying circulation of those newspapers are mentioned below:-

\begin{tabular}{|l|l|l|l|}
\hline $\begin{array}{l}\text { SR. } \\
\text { NO. }\end{array}$ & NEWSPAPER & JANUARY - JUNE 2010 & JULY - DECEMBER 2010 \\
\hline 1. & The Telegraph & $4,73,690$ & $4,81,755$ \\
\hline 2. & The Statesman & $1,72,195$ & Not accepted by ABC \\
\hline 3. & The Times of India & $3,93,587$ & $4,06,133$ \\
\hline 4. & Hindustan Times & 60,000 & 60,000 \\
\hline 5. & Anandabazar Patrika & $11,73,751$ & $11,85,779$ \\
\hline 6. & Bartaman & $4,85,449$ & $4,88,425$ \\
\hline 7. & Aajakal & $1,81,431$ & $1,81,353$ \\
\hline 8. & Sambad Pratidin & $3,06,644$ & $3,06,337$ \\
\hline 9. & Ganashakti & $1,51,822$ & $1,57,502$ \\
\hline
\end{tabular}

\{Source: Audit Bureau of Circulations(ABC), excepting the data of Hindustan Times\} 
To find the status of media coverage and the current trends in local print media coverage of environmental news in local leading print media, the news items published in aforesaid nine different prominent dailies were collected according to a well defined sampling procedure through which a broad spectrum of environmental science categories may be covered for long 72 months during $1^{\text {st }}$ January, 2005 to $31^{\text {st }}$ December, 2010. No promotional feature has been considered.

This was a very sturdy task to organize all the information, which has significant position in this research. All the available paper clippings on environment related news published in previously mentioned newspapers for long 72 months during $1^{\text {st }}$ January, 2005 to $31^{\text {st }}$ December, 2010 have been organized month wise so that the convenient information can be marked out easily. All the information has been analyzed using database designed on MS Access platform.

\section{ANAlysis}

\subsection{Explanation}

Date wise total available 20,697 news published in nine different newspapers as various 'Report Types' during January 2005 to December 2010, have been shown in the Chart - 1 and table - 1 .

\subsection{Observation}

1. Highest total numbers of news (897) were published on $5^{\text {th }}$.

2. Second highest total numbers of news (877) were published on $6^{\text {th }}$.

3. Highest total numbers of news $(897+877+729+771+772+743=4,789)$ were published during continuous six days $\left(5^{\text {th }}\right.$ to $\left.10^{\text {th }}\right)$. This trend was not seen in any other continuous days.

4. Considerable period of 72 months during $1^{\text {st }}$ January, 2005 to $31^{\text {st }}$ December, 2010, a total of 30 months did not have the date $31^{\text {st }}$. So, excepting the date $31^{\text {st }}$, lowest numbers of news (551) published on $26^{\text {th }}$.

\section{REMARKS}

\subsection{Set - A}

1. Highest total numbers of news (897) were published on day 5th during six years, indicating that these numbers of news were published on 72 numbers of days $5^{\text {th }}$ at an average of 12.45 numbers of news per day by nine news papers.

2. More interestingly, a total of 204 numbers of news were published on June $5^{\text {th }}$ alone during six years, indicating that these numbers of news were published on only six numbers of days June $5^{\text {th }}$ at an average of 34 numbers of news per day by nine newspapers.

3. Similar trend also has been observed in case of June $6^{\text {th }}, 7^{\text {th }}$ and $8^{\text {th }}$ in which averages of per day news published on six days of June $5^{\text {th }}$ are bigger than average of per day news published on 72 numbers of days $5^{\text {th }}$.

4. World Environment Day has been celebrated on June $5^{\text {th }}$ across the globe for which maximum total numbers of news were published.

5. Not only the day of June $5^{\text {th }}$, has the similar trend been continued three more days. In these three days, news of celebration of World Environment Day and other environmental news were published in lofty numbers, signifying that a day dedicated for environment influenced all the media.

\subsection{Set - B}

6. Number of news published per day has been gradually decreased towards the end of the month.

7. Decreasing trend of number of news published per day towards the end of the month has been shown.

\section{Conclusion}

From the above study, this may be concluded that all the local newspapers played an influential role to upgrade society environmentally by publishing environmental news regular basis. But the decreasing trend of number of news published per day towards the end of the month has been shown. 
Day Wise Trend of the Environmental News Published Per Month: A Critical Study

\section{Table1.}

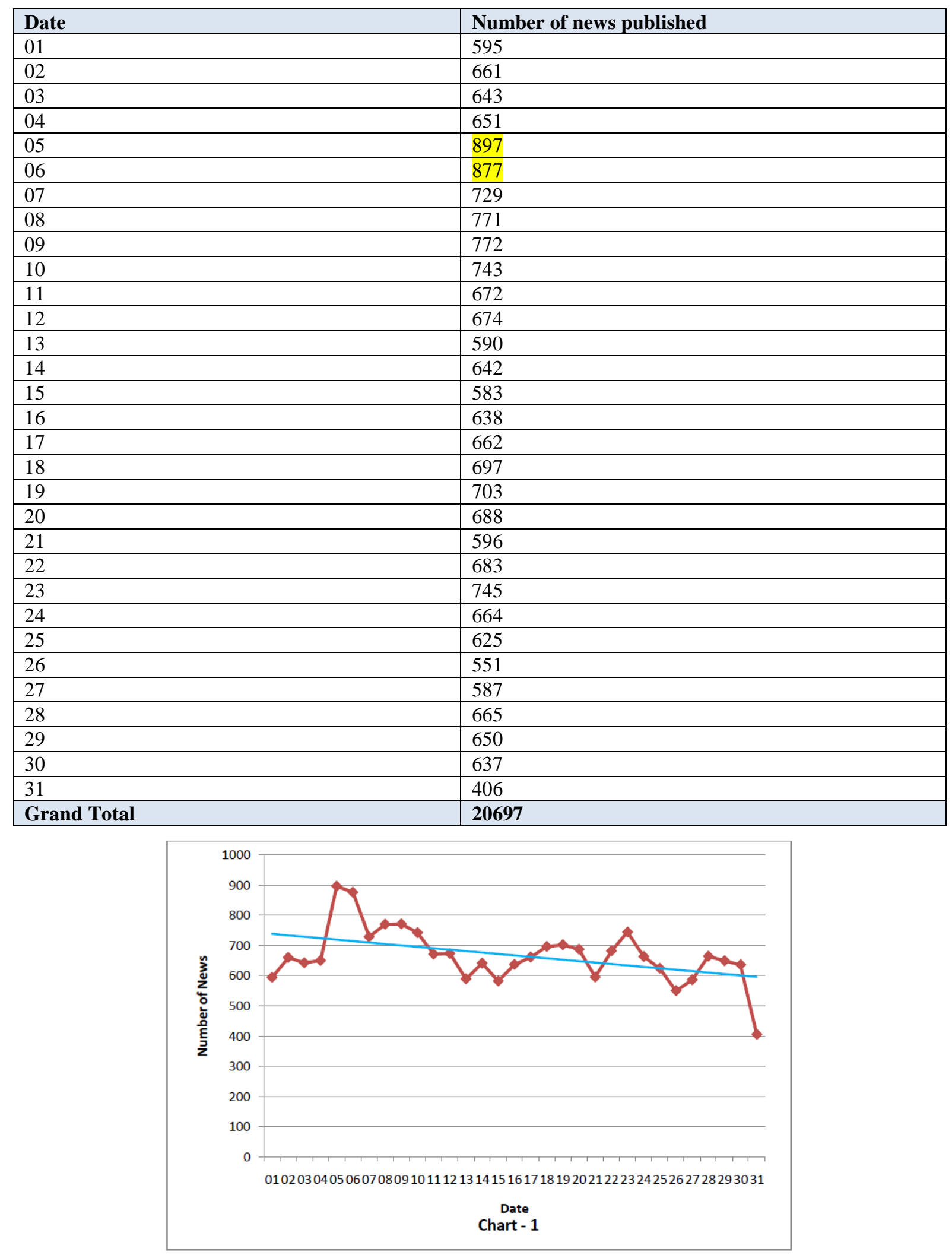

\section{REFERENCES}

${ }^{1}$ Yenne, Bill (2010). Alexander the Great: Lessons From History's Undefeated General. Palmgrave McMillan, p 159

${ }^{2}$ Simon Hornblower, "Greek Identity in the Archaic and Classical Periods" in KaterinaZacharia, Hellenisms, Ashgate Publishing, 2008, pp 55-58 
${ }^{3}$ M. M. Austin, "The Hellenistic World from Alexander to the Roman Conquest: a selection of ancient sources in translation", Cambridge University Press, 2006, p 3

${ }^{4} \mathrm{http}: / /$ www.bbc.co.uk/history/historic_figures/alexander_the_great.shtml (As viewed on 01.09.2016)

${ }^{5}$ https://en.wikipedia.org/wiki/Alexandria_(disambiguation)\#Other_places_founded_or_renamed_Alexandria

_by_Alexander_the_Great (As viewed on 02.09.2016)

${ }^{6}$ https://en.wikipedia.org/wiki/Alexander_the_Great (As viewed on 02.09.2016)

${ }^{7}$ Sabin, P, van Wees, H, Whitby, M (2007). The Cambridge History of Greek and Roman Warfare: Greece, the Hellenistic World and the Rise of Rome, Cambridge University Press.

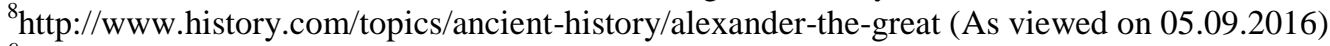

${ }^{9}$ Yenne, Bill (2010). Alexander the Great: Lessons From History's Undefeated General. Palmgrave McMillan.

${ }^{10}$ Gunther, John (2007, Alexander the Great, Sterling

${ }^{11}$ https://www.theguardian.com/books/2014/jan/30/whos-most-significant-historical-figure (as viewed on 02.09.2016) ["Guardian on Time Magazine's 100 personalities of all time"]

${ }^{12}$ Heckel, Waldemar; Tritle, Lawrence A., eds. (2009)."The Corinthian League". Alexander the Great: A New History. Wiley-Blackwell. p 99

${ }^{13}$ Burger, Michael (2008). The Shaping of Western Civilization: From Antiquity to the Enlightenment.University of Toronto Press. p 76

${ }^{14}$ https://en.wikipedia.org/wiki/Alexander_the_Great (As viewed on 02.09.2016)

${ }^{15}$ Tripathi, Rama Shankar (1999),History of Ancient India, MotilalBanarasidass Publishers Private Limited, Delhi

${ }^{16}$ Tripathi, Rama Shankar (1999),History of Ancient India, MotilalBanarasidass Publishers Private Limited, Delhi, pp 118-121

${ }^{17}$ Narain, A. K. (1965). Alexander the Great: Greece and Rome-12

${ }^{18}$ Tripathi, Rama Shankar (1999),History of Ancient India, MotilalBanarasidass Publishers Private Limited, Delhi, pp 124-125

${ }^{19}$ Tripathi, Rama Shankar (1999),History of Ancient India, MotilalBanarasidass Publishers Private Limited, Delhi, pp 129-130

${ }^{20} \mathrm{http}$ //www.sierraclub.org/sierra/2014-4-july-august/green-life/how-much-paper-does-one-tree-produce(As viewed on 19.01.2016)

${ }^{21} \mathrm{http}: / /$ www.oppapers.com/essays/Shortcomings-Of-Print-Media/566644

${ }^{22} \mathrm{http}: / /$ work.chron.com/advantage-disadvantage-print-electronic-media-3840.html (as viewed on 12.09.2016)

${ }^{23}$ Downs, A., (1972), Up and Down with Ecology, Public Interest, 28:38 -50

${ }^{24} \mathrm{http} / / /$ politicalclimate.net/2011/05/02/up-and-down-with-climate-change/\#comments (As viewed on 18.01.2016)

${ }^{25}$ Lowe, P., and Morrison, D., (1984), Bad news or good news: Environmental politics and the mass media, American Sociological Review, 32, pp75 - 90

${ }^{26}$ Molotch, H.,(1975), Accidental news: The great oil spill, American Journal of Sociology, 81, pp 235-260

${ }^{27}$ Gamsom, W.A. et al., (1992) Talking Politics, New York, Cambridge University Press

${ }^{28}$ World Press Trends Report 2012. (2012). WAN-IFRA Research SFN.Darmstradt, Germany

${ }^{29}$ Press In India 2010-2011, (2012). 55th Annual Report.Jayraj, T. (Ed.), TheRegister of Newspapers for India. New Delhi.

${ }^{30}$ Kamath, M.V., (2005), Professional Journalism,Vikas Publishing House Pvt Ltd, New Delhi

${ }^{31}$ Meheta, D.S.,(1979), Mass Communication and Journalism in India, Allied Publishers Pvt. Limited, p 170

\section{BIBLIOGRAPHY}

[1] Bose, Partha (2003). Alexander the Great's Art of Strategy. Crows Nest, NSW: Allen \&Unwin.

[2] Connerney, R. D. (2009). The upside-down tree: India's changing culture. Algora. p. 214.

[3] Hart, Laurie Kain (1999). "Culture, Civilization, and Demarcation at the Northwest Borders of Greece". American Ethnologist. 26 (1): 196-220

[4] Heckel, Waldemar; Tritle, Lawrence A, eds. (2009). Alexander the Great: A New History. Wiley-Blackwell.

[5] Ghosh, Subir (1991), Mass Media Today, Profile Publishers, Calcutta

[6] http://www.buzzle.com/articles/different-types-of-mass-media.html (As viewed on 12.09.2016)

[7] Carr, C.F. and Stevens, F.E. (1946), Modern Journalism, Sir Isaac Pitman \& Sons Ltd, London

[8] http://www.wisegeek.org/what-is-mass-media.htm (As viewed on 12.09.2016)

[9] Ryan, C (1991), Prime Time Activism: Media Strategies for Grassroots Organizing, South End Press, Boston 
[10] Nath, Shyam (2005), News, Audiences and Everyday Life, Authors Press, Delhi, pp 25-27

[11] Schlesinger, P. (1987), Putting 'Reality' Together (2nd ed.),BBC News, Methuen, London

[12] Bell, Allan, (1991), The Language of News Media. Oxford: Blackwell.

[13] Shoemaker, P. and Reese, S.D. (1996) Mediating the Message. London: Longman.

[14] Baker, Russell (August 16, 2007). "Goodbye to Newspapers?". The New York Review of Books [http://www.nybooks.com/articles/2007/08/16/goodbye-to-newspapers/(as viewedon 08.09.2016 )]

[15] Baker, Russell (August 16, 2007). "Goodbye to Newspapers?".The New York Review of Books. [http://www.editorandpublisher.com/columns/how-did-newspapers-get-in-this-pickle/(As viewed on 08.09.2016)]

[16] Splichal, Slavko (2006). "In Pursuit of Socialized Press". In Berry, David \& Theobald John. Radical mass media criticism: a cultural genealogy. Black Rose Books 